chest showed no evidence of active pulmonary disease. On cholecystography the gall-bladder was considered to be nonfunctioning. $X$-ray examination of the left elbow-joint revealed no abnormality. The van den Bergh reaction gave a positive indirect result. No serum agglutinins were detected for Leptospira icterohaemorrhagiae.

By April, 1950, the left elbow-joint showed the signs of an infective arthritis, and was greatly swollen. Aspiration of the joint revealed pus, and a culture was set up. Epigastric pain was now becoming increasingly severe, and the possibility of impacted gall-stones was considered. The surgeon hesitated to operate on account of the possibility of severe haemorrhage. When the bleeding-time was found to be normal, laparotomy was carried out.

At operation, gall-stones were not found, but the liver was very congested and raw-looking, with numerous small yellow spots all over its surface. Around the liver there were many adhesions to the anterior abdominal wall and viscera. The gall-bladder was normal, but was fixed in adhesions. The head of the pancreas was slightly thickened, but was thought not to be the seat of malignant growth. A piece of the edge of the liver was removed for histological examination.

Three days after operation it became known that from the pus aspirated from the elbow-joint a culture of $M y c o-$ bacterium tuberculosis had been grown. This finding reached startling significance when the pathologist's report on the liver specimen showed that tubercle follicles were present in the liver parenchyma deep to the capsule: tubercle bacilli were not demonstrated, but the lesions were histologically typical of tuberculosis. Also, there was an increase of connective tissue in and between the portal tracts, and the surrounding liver tissue showed irregular hyperplasia and atrophy. The connective tissue contained numerous plasma cells and lymphocytes, and there was pronounced bile-duct hyperplasia. The lesions were summarized as metastatic haematogenous tuberculous follicles, and early scarring resulting from prolonged, or recurrent, and still active infective hepatitis.

\section{Streptomycin Treatment}

The problem of diagnosis, of course, now included the possibility of a dual pathology. Nevertheless, it appeared that a case of tuberculosis of the liver had been diagnosed during life without evidence of generalized miliary infection, but with a distant focus which had become manifest long after the initial symptoms of hepatic disorder. Whatever the diagnostic difficulties, there seemed to be no similar therapeutic problem. Streptomycin, which is most successful in some of the rarer manifestations of tuberculous infection, seemed to be the most reasonable basis for treatment. It was first given on May 12, $2 \mathrm{~g}$. daily being injected intramuscularly for the first five days, after which the daily dose was $1 \mathrm{~g}$. This was continued until August 22, when a total of $107 \mathrm{~g}$. had been given.

During the months of treatment the temperature, which previously had shown intermittent elevation, gradually settled and general clinical improvement began. Appetite improved steadily and there was a sustained increase in weight, though bile persisted in the urine, stools remained rather pale, and a tinge of jaundice was perceptible. The erythrocyte sedimentation rate was thought to be a useful index of progress, Westergren's method being used throughout. From the high first-hour reading of $95 \mathrm{~mm}$. on April 18 a steadily continuous fall was observed. On August 27, five days after the cessation of streptomycin administration, the comparable reading was $15 \mathrm{~mm}$.

The tuberculous arthritis of the left elbow-joint was treated by immobilization in plaster. During May the joint became unstable, and two months later was almost completely disorganized. A cold abscess pointed and discharged in the antecubital fossa, but by the end of August the resultant sinus had ceased to discharge and had filled with granulation tissue.

\section{Further Progress}

In September the patient became ambulant and seemed to be making steady progress. His appetite, however, was capricious, and injections of vitamin-B complex were given. These had the effect of making the appetite almost voracious, and a high-protein diet, rather unpalatable to an average person, was consumed with ease. Diarrhoea developed at this time, with the passage of loose, pale, unformed, and very offensive stools. They resembled closely the stool of steatorrhoea. Dietary adjustment-namely, lowering of the fat content and administration of an ox-bile preparationwas followed by immediate improvement. His general condition was now so satisfactory that he was allowed home to continue convalescence. There was no jaundice, pallor had been replaced by good colour, and his weight was 9 st. $4 \mathrm{lb}$. (59 kg.), an increase of over $14 \mathrm{lb}$. $(6.4 \mathrm{~kg}$.) since the beginning of streptomycin treatment. The elbowjoint was immobilized in plaster, in the position of flexion to just less than a right-angle, and he was quite capable of dressing and eating, etc., with only one efficient arm.

Since discharge he has been seen regularly at fortnightly intervals. The gain in weight has been maintained and his appetite has been enormous. The sedimentation rate (Westergren) on November 15 was: first hour $17 \mathrm{~mm}$., second hour $47 \mathrm{~mm}$.; and on November 29, first hour $20 \mathrm{~mm}$., second hour $47 \mathrm{~mm}$. Stools were still rather pale and loose, and there was slight tenderness in the right umbilical region. Examination of the chest still showed no abnormality. The elbow-joint was gradually becoming ankylosed.

At the time of writing the patient feels well, but, while the degree of recovery following streptomycin is as yet very satisfactory, the ultimate prognosis must remain doubtful, with the possibility of recurrence to be considered.

I wish to express my thanks to Dr. D. K. Adams for permission to describe this case, which was treated in his wards, and to Mr. G. Dalziel, who performed the laparotomy. My thanks are also extended to Dr. Adams and Dr. W. Kyles for their guidance, help, and criticism during the preparation of this paper.

\section{Medical Memorandum}

\section{Special Visits by Medical Officers of a Public Health Department}

The visits of medical officers on the staff of a public health department to suspected cases of infectious disease receive but scant publicity. During serious epidemics this work becomes more obvious, but the regular visits which take place throughout the year are but little appreciated until an epidemic such as one of poliomyelitis throws them into relief.

An analysis of a miscellaneous list of such visits covering the period 1935 to 1950 for the City of Manchester is most revealing in showing the diagnostic difficulties that are most common. A miscellaneous list has been chosen to show the range of clinical acumen necessary in this special field. An analysis of these visits is presented in the accompanying table.

The screening of cases by public health medical officers becomes increasingly important, for the available accommodation in infectious disease hospitals is limited by shortages of nursing staff and a standstill in building extensions to these hospitals. This work is essentially clinical, and requires that those undertaking it shall have 
Home Consultations by Medical Officers During 1935-50

\begin{tabular}{|c|c|c|c|c|}
\hline Disease & $\begin{array}{c}\text { Cases } \\
\text { Referred }\end{array}$ & $\begin{array}{c}\text { Cases } \\
\text { Con- } \\
\text { firmed }\end{array}$ & $\begin{array}{c}\text { Cases } \\
\text { Not Con- } \\
\text { firmed } \\
\end{array}$ & $\begin{array}{c}\text { Examples of Revised } \\
\text { Diagnosis by Consultant } \\
\text { or Hospital }\end{array}$ \\
\hline $\begin{array}{c}\text { Diphtheria } \\
\text { Faucial includes } \\
\text { pharyngeal } \\
\text { Nasal }\end{array}$ & $18^{21}$ & $5^{6}$ & $13^{15}$ & $\begin{array}{l}\text { Streptoccccal septicaemia } \\
\text { Tonsillitis, thrush, diph- } \\
\text { theria carrier }\end{array}$ \\
\hline $\begin{array}{ll}\text { Nasal } & \ldots \\
\text { Laryngeal } & \ldots \\
\text { Carrier } & \ldots\end{array}$ & $\begin{array}{l}1 \\
2 \\
\end{array}$ & 1 & $\begin{array}{l}1 \\
1 \\
-\end{array}$ & $\begin{array}{l}\text { Faucial diphtheria } \\
\text { Laryngitis }\end{array}$ \\
\hline Erysipelas & 13 & 7 & 6 & $\begin{array}{l}\text { Dermatitis, serum reaction, } \\
\text { cellulitis }\end{array}$ \\
\hline $\begin{array}{l}\text { Enteric fever (ty- } \\
\text { phoid or para- } \\
\text { typhoid) }\end{array}$ & 23 & 9 & 14 & $\begin{array}{l}\text { Henoch's purpura, malig- } \\
\text { nant disease, tonsillitis, } \\
\text { gastro-enteritis, cerebro- } \\
\text { spinal fever, colitis, infec- } \\
\text { tive endocarditis, anae- } \\
\text { mia, food-poisoning, and } \\
\text { pyelitis }\end{array}$ \\
\hline $\begin{array}{l}\text { Cerebrospinal } \\
\text { fever (menin- } \\
\text { gococcal infec- } \\
\text { tion) }\end{array}$ & 16 & 12 & 4 & $\begin{array}{l}\text { Acute purpura, rheumatic } \\
\text { fever, neurasthenia }\end{array}$ \\
\hline Measle: & 18 & 6 & 12 & $\begin{array}{l}\text { Erythema, rubella, enema } \\
\text { rash, urticaria }\end{array}$ \\
\hline $\begin{array}{l}\text { Rubella } \\
\text { Poliomyelitis (ex- } \\
\text { clusive of } 1947 \\
\text { outbreak, when } \\
100 \text { cases re- } \\
\text { ferred-51 not } \\
\text { confirmed at } \\
\text { home, } 49 \text { ad- } \\
\text { mitted to hos- } \\
\text { pital; } 16 \text { cases } \\
\text { not confirmed } \\
\text { in hospital) }\end{array}$ & $\begin{array}{r}3 \\
52\end{array}$ & 12 & $\begin{array}{r}2 \\
40\end{array}$ & $\begin{array}{l}\text { Urticaria, tonsillitis } \\
\text { Neuritis, cervical adenitis, } \\
\text { rheumatic fever, tonsil- } \\
\text { litis, pneumonia, sub- } \\
\text { arachnoid haemorrhage, } \\
\text { Bell's palsy, tuberculous } \\
\text { meningitis, epilepsy, rheu- } \\
\text { matism, hysteria, cerebra } \\
\text { thrombosis, febrile cat- } \\
\text { arrh, pharyngitis, herpes } \\
\text { zoster, arthritis, cerebro- } \\
\text { spinal fever, gastro- } \\
\text { enteritis, otitis media } \\
\text { pyelitis }\end{array}$ \\
\hline Scarlet fever .. & 50 & 33 & 17 & $\begin{array}{l}\text { Rubella, tonsillitis, urti } \\
\text { caria, sulphonamide rash, } \\
\text { measles, exfoliative der } \\
\text { matitis, septicaemia }\end{array}$ \\
\hline $\begin{array}{l}\text { Smallpox (exclu- } \\
\text { sive of } 2 \text { cases } \\
\text { confirmed from } \\
\text { outside city) }\end{array}$ & 96 & - & 96 & $\begin{array}{l}\text { Folliculitis, dermatitis } \\
\text { varicella, erythema multi } \\
\text { forme, urticaria, varicella } \\
\text { and herpes, lichen urti } \\
\text { caria, erythema, ecthyma } \\
\text { staphylococcal septicae } \\
\text { mia, purpura, varicella } \\
\text { and acne, measles, sul } \\
\text { phonamide rash, iodide } \\
\text { rash, furunculosis }\end{array}$ \\
\hline Rash ? infections & 7 & $4^{*}$ & 3 & $\begin{array}{l}\text { Measles, rubella (3), serum } \\
\text { reaction, urticaria, der } \\
\text { matitis }\end{array}$ \\
\hline P.U.O.? infections & 6 & $6^{*}$ & - & Enteric fever, pneumonia \\
\hline $\begin{array}{l}\text { Puerp } \\
\text { Misce }\end{array}$ & 6 & 5 & 1 & Mastitis \\
\hline $\begin{array}{l}\text { Mal } \\
\text { Dys } \\
\text { (b }\end{array}$ & $\begin{array}{l}2 \\
1\end{array}$ & 1 & $\begin{array}{l}1 \\
1\end{array}$ & Gastro-enteritis \\
\hline ryever & 1 & $\overline{1}$ & 1 & Nasal diphtheria \\
\hline Debi & 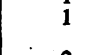 & . & - & \\
\hline $\begin{array}{l}\text { Epidemic paro- } \\
\text { titis } \\
\text { Pemphigus. .. }\end{array}$ & 2 & - & 2 & $\begin{array}{l}\text { Tonsillitis, submaxillary } \\
\text { adenitis }\end{array}$ \\
\hline a & $\begin{array}{l}2 \\
1 \\
1\end{array}$ & $\frac{2}{1}$ & $\begin{array}{l}2 \\
1 \\
\end{array}$ & $\begin{array}{l}\text { Rheumatism, scarlet feve } \\
\text { Drug idiosyncrasy }\end{array}$ \\
\hline $\begin{array}{l}\text { Hemiplegia fol- } \\
\text { lowing influ- } \\
\text { enza }\end{array}$ & 1 & & 1 & Meningitis following otiti \\
\hline $\begin{array}{l}\text { Streptococcal } \\
\text { infection }\end{array}$ & 1 & 一 & 1 & Agranulocytic angina \\
\hline $\begin{array}{c}\text { Influenzal pneu- } \\
\text { monia }\end{array}$ & 1 & - & 1 & \\
\hline Total & 328 & 107 & $221 \dagger$ & \\
\hline
\end{tabular}

* Diagnosis as in last column. +199 home consultations, 22 hospital.

not only a sound background of knowledge gained in infectious disease hospitals but also many years of experience in the art of applying this knowledge. In this connexion the table shows the numerous pitfalls of diagnosis of poliomyelitis and the need for the public to be reassured by the comparatively few cases that are confirmed. The necessity for thorough screaning of cases by experienced medical officers is essential if effective use is to be made of hospital beds.

This survey of consultations has not been made in any spirit of criticism. When one considers the list of revised diagnoses it is evident that in most cases the patient was suffering from a serious illness-in many instances requiring admission to hospital. It is intended to emphasize the need for team-work between the hospital, the medical practitioner, and the medical officer of health. There is still an important field of clinical work for the medical officer of health and a need to make the fullest use of the increasing accessory aids to diagnosis provided by the national Public Health Laboratory Service.

Reference to the table shows that only one case of bacillary dysentery was referred for home consultation and that comparatively few cases (21) of diphtheria needed a second opinion. The presumption is that in the case of diphtheria medical practitioners referred all suspicious cases to hospital ; while in the case of bacillary dysentery they obtained bacteriological diagnosis and either treated the cases at home or sent them to hospital. There is a further possibility that some cases of dysentery were treated as gastro-enteritis.

Another interesting point is that there is an excellent confirmation rate for meningococcal infection (12 out of 16 cases) but confirmation rates for smallpox and poliomyelitis are low. A factor operating in these two serious diseases and responsible for the low confirmation rate is the anxiety of the medical practitioner not to miss the disease. The variety of revised diagnoses underlines this difficulty.

Ovér a period of 15 years, and exclusive of epidemics, as many cases of suspected poliomyelitis as of suspected scarlet fever were referred to the health department for a second opinion; this number represents one-sixth of the total cases. One might have expected a higher confirmation rate in diseases such as erysipelas, enteric fever, and measles.

\section{Conclusions}

A survey of 328 home consultations by medical officers of a health department over a period of 15 years has been made. These visits are exclusive of those carried out during major epidemics.

The diagnosed infection was not confirmed in 221 cases-199 after home consultation and 22 after admission to hospital. This represents very effective screening of cases and a. considerable saving in hospital accommodation.

Examples are given of the variety of conditions which make the diagnosis of the specific infectious diseases a matter of considerable difficulty and call for the specia!ized training of medical officers of the public health service. The necessary team-work, with medical practitioners and laboratory and hospital services, leads to efficient administration in the control of infectious diseases in the community.

L. R. L. Edwards, M.D., D.P.H., Senior Assistant Medical Officer of Health, City of Manchester.

N.A.P.T. has just published the 13th edition of the Handbook of Tuberculosis Activities in Great Britain and the Commonwealth. This is a complete directory of hospitals, sanatoria, clinics, regional hospital boards, hospital management committees, and tuberculosis services in the British Commonwealth, including addresses and telephone numbers. It is the first edition of the handbook to be published since the start of the Health Service, and therefore there is much new material presented. 